\title{
YEAST ARTIFICIL CHROMOSOME (YAC) CLONES AND SEQUENCE TAGGED SITE (STS) MARKERS ANCHORED AT HUMAN CHROMOSOME 21
}

\author{
Toshihiko Eki, ${ }^{1, *}$ Kazushige Yokoyama, ${ }^{1}$ Hiroyuki Tashiro, ${ }^{1}$ \\ Kazuo Ozawa, ${ }^{1}$ Yasufumi Murakami, ${ }^{1}$ Paul C. Watkins, ${ }^{2}$ \\ and Ei-ichi SoEDA ${ }^{1}$ \\ ${ }^{1}$ Gene Bank, Tsukuba Life Science Center, RIKEN (The Institute of Physical and \\ Chemical Research), 3-1-1 Koyadai, Tsukuba, Ibaraki 305, Japan \\ " Genome Analysis Technology Department, Life Technologies, Inc., \\ 8717 Grovemont Circle, Gaithersburg, MD 20877, U.S.A.
}

Key Words YAC clone, human chromosome 21, STS marker, PCRmediated screening

Human chromosome 21 has been well-characterized genetically because it includes several potential genes involved in numerous inherited disorders, particularly Down syndrome (Scoggin and Patterson, 1982) and familial Alzheimer's disease (St. George-Hyslop et al., 1987). Several known genes or restriction fragment length polymorphic (RFLP) DNA markers have been mapped regionally on chromosome 21 (Watkins et al., 1985, 1987; Tanzi et al., 1988). In order to clarify genome structure and to define molecular bases of these inherited disorders, great efforts to make a physical map have been made during the past decades.

Yeast artificial chromosome (YAC) vector developed recently provides a powerful tool for cloning several hundred kilobases of exogenous DNA in yeast cells and has allowed us to analyze a large region of human genome (Burke et al., 1987; Hieter et al., 1990; Imai and Olson, 1990a; Kai et al., 1990; Yokoyama et al., 1990).

We have constructed a YAC library from a human lymphoblastoid cell line, CGM-1 according to the Burke's method (Burke and Olson, 1990) with a slight modification (Imai and Olson, 1990a). The library contains 14,000 clones with an average insert DNA size of $360 \mathrm{~kb}$ and the total length of human insert DNA was estimated approximately to be two equivalents of human haploid genome.

We have chosen several known genes and RFLP markers localized in chromosome 21 in order to isolate YAC clones by using the polymerase chain reaction

Received September 9, 1991; Accepted October 15, 1991.

* To whom correspondence and request for reprints should be addressed. 


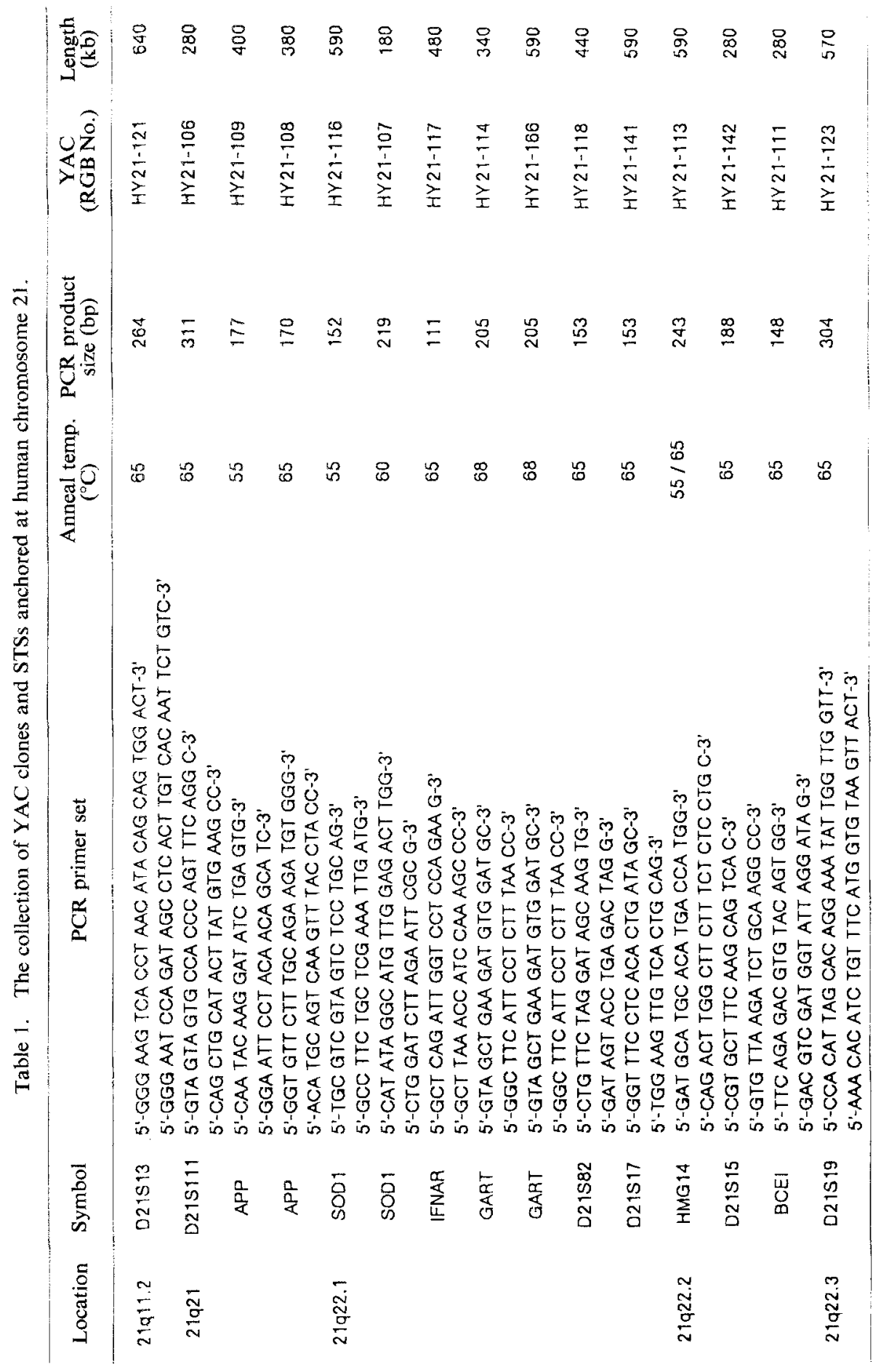

Jpn. J. Human Genet. 
(PCR) with a pair of oligodeoxynucleotide primers designed from the nucleotide sequences of each DNA fragment (Green and Olson, 1990; Anand et al., 1991). Five microliters of reaction mixture contains $50 \mathrm{ng}$ of DNAs from YAC library, $5^{\prime}$ - and $3^{\prime}$-end primers at a concentration of $25 \mu \mathrm{M}$ in $50 \mathrm{~mm} \mathrm{KCl}, 10 \mathrm{~mm}$ Tris- $\mathrm{HCl}$, $\mathrm{pH} 8.3,2.5 \mathrm{mM} \mathrm{MgCl}_{2}, 0.01 \%$ gelatin (Sigma, \#G-2500), dATP, dCTP, dGTP, and TTP at $200 \mu \mathrm{M}$ each (TaKaRa, Kyoto), and 0.25 unit of recombinant Taq polymerase (Perkin Elmer Cetus) with $20 \mu$ of mineral oil overlay for 35 cycles at $94^{\circ} \mathrm{C}$ for denaturation $(1 \mathrm{~min})$, at the indicated temperature $\left(55-65^{\circ} \mathrm{C}\right)$ in Table 1 for annealing $(2 \mathrm{~min})$, and at $72^{\circ} \mathrm{C}$ for polymerization $(2 \mathrm{~min})$ in a Perkin Elmer Cetus automated thermal cycler.

The library was screened for positive YAC clones with a combination of PCR and filter hybridization. Eight pools of DNAs from five pooled DNA of master plate each, were screened by PCR by the methods of Green and Olson (1990) and Anand et al. (1991). In a second round of PCR screening, master pools of DNAs from the positive DNA pools were tested. A DNA pool of master plate was prepared from one filter representing a set of 384 YAC clones. Finally, positive YAC clones were detected by colony hybridization with the appropriate ${ }^{32} \mathrm{P}-$ labeled PCR product. Subsequent positive YAC clones were analyzed further by pulse-field gel electrophoresis and successive Southern blot hybridization to determine the size of insert DNA as described previously (Imai et al., 1990b).

We have successively isolated fifteen YAC clones from the library by PCRmediated screening and these results were summarized in Table 1. Twelve YAC clones were assigned to chromosome $21 \mathrm{q} 22$ and the others to $21 \mathrm{q} 11$ or $21 \mathrm{q} 21$. The total length of human DNA inserts was calculated about $6.6 \mathrm{Mb}$, which is equivalent to $16.5 \%$ that of the human chromosome 21 . With these YAC clones anchoring at chromosome 21 , we are now trying to isolate YAC linking clones to make a contig map of human chromosome 21 by means of "inverse-PCR" (Riley et al., 1990) or "YAC-Alu PCR" (Breukel et al., 1990; Cole et al., 1991; Tashiro et al., 1991).

\section{REFERENCES}

Anand, R., Ogilvie, D.J., Butler, R., Riley, J.H., Finnjear, R.S., Powell, S.J., Smith, J.C. and Markham, A.F. 1991. A yeast artificial chromosome contig encompassing the cystic fibrosis locus. Genomics 9: 124-130.

Breukei, C., Wijnen, J., Tops, C., Klift, H. v/d., Dauwerse, H. and Khan, P.M. $1990 . \quad$ Vector- $A l u$ PCR: a rapid step in mapping cosmids and YACs. Nucleic Acids Res. 18: 3097.

Burke, D.T., Cale, G.F. and Olson, M.V. 1987. Cloning of large segments of DNA into yeast by means of artificial chromosome vectors. Science 236: 806-812.

Burke, D.T. and Olson, M.V. 1990. Preparation of clone libraries in yeast artificial chromosome vectors. Methods Enzymol. 194: 251-270.

Cole, C.G., Goodfellow, P.N., Bobrow, M. and Bentley, D.R. 1991. Generation of novel sequence tagged sites (STSs) from discrete chromosomal regions using Alu-PCR. Genomics 10: 816826.

Green, E.D. and Olson, M.V. 1990. Systematic screening of yeast artificial chromosome libraries by use of the polymerase chain reaction. Proc. Natl. Acad. Sci. U.S.A. 87: 1213-1217. 
Hieter, P., Conneliy, C., Shero, J., McCormick, M.K., Antonarakis, S., Pavan, W. and Reeves, R. 1990. Yeast artificial chromosomes: Promises kept and pending. In Genetic and Physical Mapping, Vol. 1, Genome Analysis, Davies, K.E. and Tilghman, S.M., eds., Cold Spling Harbor Laboratory Fress, New York, pp. 83-120.

Imai, T. and Olson, M.V. 1990a. Second-generation approach to the constraction of yeast artificial chromosome libraries. Genomics 8: 297-303.

Imai, T., Iida, A., Miwa, T., Tashiro, H., Song, J.-C., Yokoyama, K. and Soeda, E. 1990b. Anaiysis of YAC clones by pulse-field gel electrophoresis: Physical mapping of $\mathrm{Cu} / \mathrm{Zn}$ superoxide dismutase gene locus. Methods 1: 180-185.

Kai, T., Song, I.-C., Tashiro, H., Saka, F., Ozawa, K., Miwa, T., Kitabayashi, I., Soeda, E. and Yokoyama, K. 1990. Rapid method for cunstraction of yeast artificial chromosome human. DNA libraries involving the trapping of cells in agarose films. FEBS Lett. 275: 77-82.

Riley, J.H., Butler, R., Ogilvie, D.J., Finniear, R., Jenner, D., Anand, R., Snith, J.C. and Markham, A.F. 1990. A novel, rapid method for the isolation of terminal sequences from yeast artificial chromosome (YAC) clones. Nucleic Acids Res. 18: 2887-2890.

Scoggin, C.H. and Patterscn, D. 1982. Down syndrome as a model disease. Arch. Intern. Med. 142: 462-464.

St. George-Hyslop, P.H., Tanzi, R.E., Polinsky, R.J., Haines, J.L., Nee, R.G., Watkins, P.C., Myers, R.H., Feldman, R.G., Pollen, D., Drachman, D., Growdon, J., Bruni, A., Foncin, J.F., Salmon, D., Fromment, P., Amaducci, L., Sorbi, S., Piacentini, S., Stewart, G.D., Hobbs, W.J., Conneally, P.M. and Gusella, J.F. 1987. The genetic defect causing familial Alzheimer's disease maps on chromosome 21. Science 235: 885-890.

Tanzi, R.E., Haines, J.L., Watkins, P.C., Stewart, G.D., Wallace, M.R., Hallewell, R., Wong, C., Wexler, N.S., Conneally, P.M. and Gusella, J.F. 1988. Genetic linkage map of human chromosome 21. Genomics 3: 129-136.

Tashiro, H., Ozawa, K., Xiaoren, T., Nakai, H., Eki, T., Murakami, Y., Soeda, E. and Yokoyama, K. 1991. Single DNA marker generated by "YAC-Alu PCR" that is end-specific. Jpn. J. Human Genet. 36: 229-243.

Watkins, P.C., Tanzi, R.E., Gibbons, K.T., Tricoli, J.V., Landes, G., Eddy, R., Shows, T.B. and Gusella, J.F. 1985. Isolation of polymorphic DNA segments from human chromosome 21. Nucleic Acids Res. 13: 6075-6088.

Watkins, P.C., Tanzi, R.F., Cheng, S.V. and Gusella, J.F. 1987. Molecular genetics of human chromosome 21. J. Med. Genet. 24: 257-270.

Yokoyama, K., Saka, F., Kai, T. and Soeda, E. 1990. Encapsulation of cells in agarose beads for use in the construction of human DNA libraries as yeast artificial chromosomes (YAC). Jpn. J. Human Genet. 35: 131-143. 